\title{
Phenotype of definite familial hypercholesterolemia with negative genetic study in Argentina
}

\author{
Fenotipo de hipercolesterolemia familiar definitivo con estudio genético negativo en \\ Argentina
}

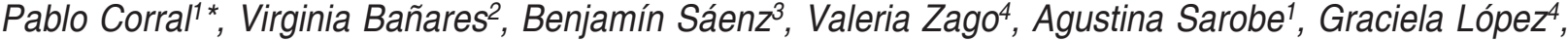 \\ Gabriela Berg', and Laura Schreier ${ }^{4}$ \\ ${ }^{1}$ Cátedra de Farmacología, Facultad de Medicina, Universidad FASTA; ${ }^{2}$ Departamento de Genética Experimental, Centro Nacional de Genética \\ Medica "Dr. Eduardo Castilla", Administración Nacional de Laboratorios e Institutos de Salud "Dr. Carlos Malbran"; ${ }^{3}$ Departamento de Investigación, \\ Facultad de Medicina, Universidad FASTA; ${ }^{4}$ Facultad de Farmacia y Bioquímica, Departamento de Bioquímica Clínica, Universidad de Buenos \\ Aires, Laboratorio de Lípidos y Aterosclerosis, INFIBIOCUBA. Buenos Aires, Argentina
}

\begin{abstract}
Objective: Familial hypercholesterolemia $(F H)$ is a monogenic disease, associated with variants in the LDLR, APOB and PCSK9 genes. The initial diagnosis is based on clinical criteria like the DLCN criteria. A score $>8$ points qualifies the patient as "definite" for FH diagnosis. The detection of the presence of a variant in these genes allows carrying out familial cascade screening and better characterizes the patient in terms of prognosis and treatment. Methods: In the context of the FH detection program in Argentina (Da Vinci Study) 246 hypercholesterolemic patients were evaluated, 21 with DLCN score > 8 (definite diagnosis). These patients were studied with next generation sequencing to detect genetic variants, with an extended panel of 23 genes; also they were adding the large rearrangements analysis and a polygenic score of 10 SNP (single nucleotide polymorphism) related to the increase in LDL-C. Results: Of the 21 patients, 10 had variants in LDLR, 1 in APOB with APOE, 1 in LIPC plus elevated polygenic score, and 2 patients showed one deletion and one duplication in LDLR, the later with a variation in LIPA. It is highlighted that 6 of the 21 patients with a score $>8$ did not show any genetic alteration. Conclusions: We can conclude that $28 \%$ of the patients with definite clinical diagnosis of FH did not show genetic alteration. The possible explanations for this result would be the presence of mutations in new genes, confusing effects of the environment over the genes, the gene-gene interactions, and finally the impossibility of detecting variants with the current available methods.
\end{abstract}

Key words: Familial hypercholesterolemia. Genetic diagnosis. Polygenic score.

\section{Resumen}

Objetivo: La hipercolesterolemia familiar (HF) es una enfermedad monogénica asociada a variantes en los genes RLDL, APOB y PCSK9. El diagnóstico inicial se basa en criterios clínicos, como el de la red de clínica de lípidos holandesa (DLCN).

Correspondence:

*Pablo Corral

E-mail: drpablocorral@gmail.com
Available online: 04-09-2020 Arch Cardiol Mex (Eng). 2020;90(2):130-136 www.archivoscardiologia.com 2604-7063 / @ 2019 Instituto Nacional de Cardiología Ignacio Chávez. Published by Permanyer. This is an open access article under the CC BY-NC-ND license (http://creativecommons.org/licenses/by-nc-nd/4.0/). 
Un puntaje > 8 puntos califica al paciente como "definitivo" para diagnóstico de HF. La identificación de una variante en estos genes permite realizar el cribado en cascada familiar y caracterizar mejor al paciente en cuanto al pronóstico y el tratamiento. Métodos: En el marco del Programa de Detección de HF en Argentina (Estudio Da Vinci) se evaluó a 246 pacientes hipercolesterolémicos, 21 con puntaje $D L C N>8$ (diagnóstico definitivo). Se estudió a estos pacientes con secuenciación de próxima generación para reconocer variantes genéticas, con un panel ampliado de 23 genes, sumado al análisis de grandes rearreglos y por último se aplicó un score poligénico de 10 SNP (polimorfismo de nucleótido único) relacionados con aumento del C-LDL. Resultados: De los 21 pacientes, 10 presentaron variantes en RLDL, uno en APOB junto a APOE, uno en LIPC más puntaje poligénico elevado, dos pacientes con una deleción y una duplicación en RLDL y este último caso con una variante en LIPA. Es destacable que 6 de los 21 pacientes con puntaje DLCN > 8 no mostraron ninguna alteración genética. Conclusiones: El $28 \%$ de los pacientes con diagnóstico clínico definitivo de HF no evidenció alteración genética. Las posibles explicaciones de este resultado serían la presencia de mutaciones en nuevos genes, los efectos confundidores del ambiente sobre los genes o la interacción gen-gen y por último la imposibilidad de detectar variantes con la metodología actual disponible.

Palabras clave: Hipercolesterolemia Familiar. Diagnóstico genético. Score poligénico.

\section{Introduction}

Familial hypercholesterolemia $(\mathrm{FH})$ is a monogenic, autosomal dominant disease, associated with variants in the low-density lipoprotein receptor $(L D L R)$, apolipoprotein $\mathrm{B}(A P O B)$, and proprotein convertase subtilisin/ kexin type 9 (PCSK9) genes ${ }^{1}$.

Patients who are carriers this pathology often are asymptomatic, with low-density lipoprotein cholesterol (LDL-C) values $>200 \mathrm{mg} / \mathrm{dL}$, or have early cardiovascular events $(<50$ years in males and $<60$ years in females). Characteristics of their inheritance allow identifying affected relatives and multiple members in a single family with high levels of LDL-C or cardiovascular events ${ }^{2}$.

Initial diagnosis is based on different clinical criteria that assess the personal and family cardiovascular history and characteristic clinical stigmas, such as tendon xanthomas and early corneal arcus, and finally, LDL-C plasma values. The Dutch Lipid Clinics Network (DLCN) criteria are the most widely used. A value $>8$ points qualifies the patient as "definite" for $\mathrm{FH}$ diagnosis ${ }^{3}$.

Considering that inheritance is autosomal dominant and that the heterozygous form of $\mathrm{FH}$ is an effect of a single monogenic variant in one of the three $\mathrm{FH}$-related primary genes at the following proportions: $L D L R, 95 \%$; $A P O B, 3 \%$; and PCSK $9,1 \%$, in addition to increased availability of access to modern sequencing techniques, genetic diagnosis is a central tool in the $\mathrm{FH}$ diagnosis of $\mathrm{FH}^{4}$.

After verifying the absence of a variation or point mutation in any of these three genes, it is imperative ruling out the presence of so-called major rearrangements, essentially duplications or deletions, with molecular biology techniques or bioinformatics, which cannot be detected by gene sequencing. Different reports show that $60-80 \%$ of patients with a definite $\mathrm{FH}$ diagnosis by clinical criteria have $\mathrm{FH}$-related genetic variants $^{4-7}$.

In turn, verification of the presence of a variant in FH-linked genes allows cascade screening in the rest of the family and better patient characterization for prognosis and treatment ${ }^{8}$.

In patients with a phenotype consistent with $\mathrm{FH}$ and with no detected variants, polygenic causes explain most cases. Different groups of researchers have developed calculations to obtain a score based on single nucleotide polymorphisms (SNP) related to increased circulating LDL-C values ${ }^{5,9}$. Finally, pointing out other potential causes of cases phenotypically consistent with $\mathrm{FH}$ without genetic findings is possible, including rare mutations in other minor genes related to lipid metabolism, such as apolipoprotein $\mathrm{E}$ gene $(A P O E)$, ABCG5, ABCG8, lipase A gene (LIPA), CYP27A1 or $S T A P 1$, and mutations or variants that are inaccessible with exome sequencing ${ }^{10}$.

The purpose of this work is to evaluate of a group of patients with $\mathrm{FH}$ phenotype and definite diagnosis and negative genetic result, after complete and expanded biomolecular analysis.

\section{Materials and methods}

Two-hundred and forty-six patients with hypercholesterolemia who were included during 2016 in the $\mathrm{FH}$ Detection Program in Argentina (Da Vinci Study), carried out at Partido de General Pueyrredón, Provincia de Buenos Aires, were assessed. The participants had cholesterol levels > $300 \mathrm{mg} / \mathrm{dL}$ and/or LDL-C > $190 \mathrm{mg} / \mathrm{dL}$ and granted informed consent for clinical, biochemical, 
and genetic evaluation. The study was approved by the Ethics Committee, Res CD FFyB Res CD 1762/17.

From each patient, family and personal history was obtained, with special focus on cardiovascular atherosclerotic disease (angina pectoris, myocardial infarction, myocardial revascularization surgery, stroke, and/ or peripheral or carotid vascular disease), hospitalizations, hypertension, diabetes mellitus, and current lipid-lowering treatment. Careful physical examination, with special interest in the detection of tendon xanthomas or corneal arcus was carried out. When available, these data were obtained from first-degree relatives (parents, children, and siblings). Premature cardiovascular disease was regarded as the presence of any of the previously mentioned atherosclerotic cardiovascular disease manifestations, before 55 years of age for men and 65 for women. The DLCN criteria were applied, considering the highest LDL-C recorded value ${ }^{3}$. A total of $40 \%$ of patients received lipid-lowering treatment, and when LDL-C data off medication were not available, an LDL-C correction was applied based on the dose and potency of the statin being used ${ }^{11}$.

Twenty-one subjects were not included due to the following exclusion criteria: $\mathrm{n}=8$ had a thyroid-stimulating hormone $(\mathrm{TSH})$ value $>10 \mathrm{mlU} / \mathrm{L}$, four with creatinine $>1.7 \mathrm{mg} / \mathrm{dL}$, two with alkaline phosphatase $>200 \mathrm{U} / \mathrm{L}$, one patient with triglycerides $>1000 \mathrm{mg} / \mathrm{dL}$, three women were excluded due to pregnancy, and three patients who refused to having a blood sample taken. Therefore, 225 subjects with potential FH were finally included.

The blood samples were collected in a non-fasting state and sent to the Lipid and Atherosclerosis Laboratory of the University of Buenos Aires for biochemical analysis. Serum total cholesterol, triglycerides, high-density lipoprotein cholesterol (HDL-C), direct LDL-C, creatinine, and alkaline phosphatase were determined using standardized enzymatic methods (Roche Diagnostics, Mannheim, Germany) in a Cobas C-501 autoanalyzer. Average intra-analysis coefficient of variation $(\mathrm{CV})$ for all parameters was $<2.3 \%$ and inter-analysis CV $<3.0 \%$. Apoprotein B was determined by immunoturbidimetric method in the same autoanalyzer, with an inter-analysis CV $<2.5 \%$. TSH was measured by chemiluminescence (DPC, Immulite, Los Angeles, CA, USA) with intra-analysis and inter-analysis $\mathrm{CV}<3.5 \%$.

In all subjects with a DLCN score $>8$, genetic study was carried out. Patient DNA was extracted from the whole blood sample at the Centro Nacional de Genética Médica $^{12}$. The genetic study was carried out at Boston
Heart Diagnosis, Massachusetts, USA, using next-generation sequencing, as described in a previous study ${ }^{13}$, to identify genetic variants in classical genes related to elevated LDL-C: $L D L R, A P O B, P C S K 9$, and in other genes associated with dyslipidemia: LDLRAP1, STAP1, ABCG5, ABCG8, APOE, LIPA, CYP27A1, LIPC, LIPG, and DHCR24. In addition, a panel of ten common variants (SNP) was studied in the following genes: rs6544713 in $A B C G 8$, rs515135 in $A P O B$, rs12740374 in CELSR2, rs3846663 in HMGCR, rs2650000 in HNF1, rs6511720 in LDLR, rs6102059 in MAFB, rs10401969 in NCAN, rs11206510 in PCSK9, and rs1501908 in TIMD4. Based on the detected SNPs, the genetic risk score (GRS) was calculated to assess the polygenic contribution to increased LDL-C ${ }^{14}$. Finally, bioinformatics analysis of the copy number variations (CNV) was carried out to identify large rearrangements in the structure of genes that are not detected by genetic sequencing ${ }^{15}$.

Data are expressed as median (range) according to their distribution and percentage of prevalence. Statistical analysis was carried out with SPSS 19.0.

\section{Results}

Twenty-one of the 225 studied patients with hypercholesterolemia had a DLCN score $>8$, with an interval of 9 to 14. Out of these 21 patients with definite $\mathrm{FH}$ clinical diagnosis, two had first-degree relatives with cardiovascular disease, median (range) LDL-C of $250 \mathrm{mg} / \mathrm{dL}$ (181-431), which corresponded to the highest value eventually recorded or corrected at the end for the received treatment. Nine patients had arcus corneal arcus before 45 years of age; eight, tendon xanthomas; three, premature coronary heart disease; and two, early cerebral arterial disease. The rest of the lipid profile showed a median (range) of triglycerides: $121 \mathrm{mg} / \mathrm{dL}$ (62-314); HDL-C: $50 \mathrm{mg} / \mathrm{dL}$ (36-68); and APOB: $164 \mathrm{mg} / \mathrm{dL}$ (91-278).

Ten of the 21 patients with definite $\mathrm{FH}$ phenotype showed variants in $\angle D L R$ and one in $A P O B$, together with a variant in $A P O E$, which accounted for $52.4 \%$ of patients who have point variants in classical genes. The study of the expanded panel of genes in patients with definite phenotype also revealed one case with mutation in $L I P C$, one with variant in LIPA, and another in CYP27A1. Table 1 shows the detected variants, as well as their classification with regard to their pathogenicity.

The CNV a posteriori bioinformatics study to detect large rearrangements in the gene structure showed that 


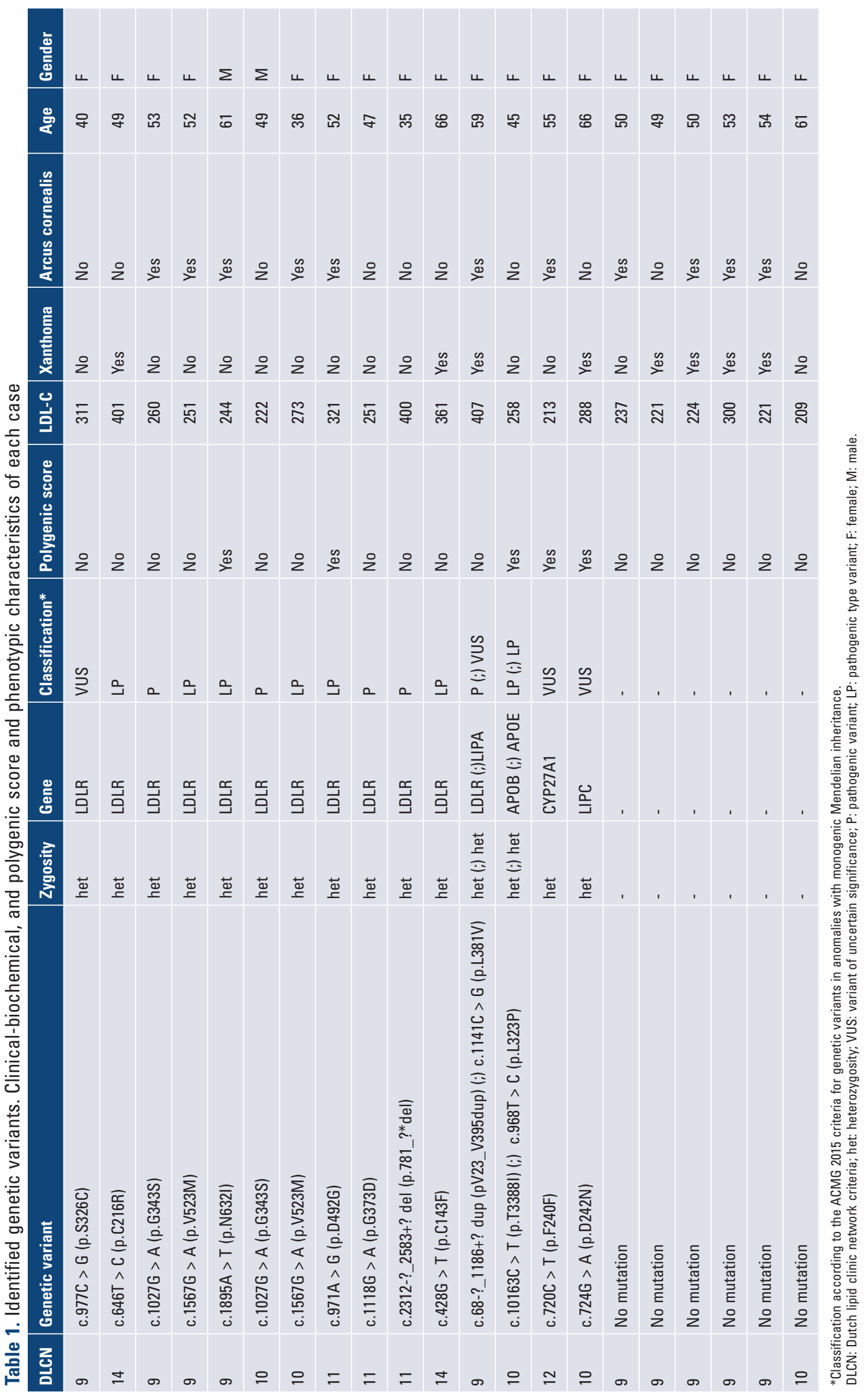




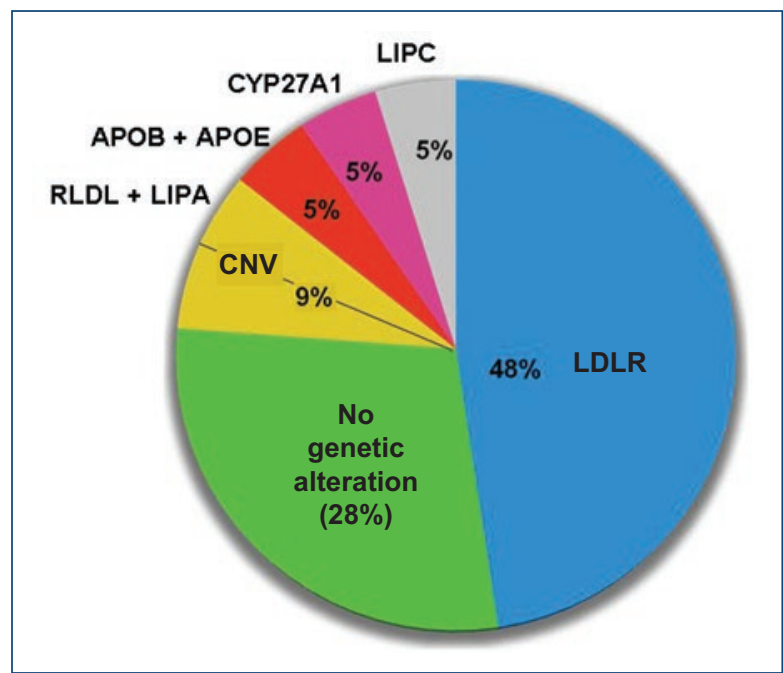

Figure 1. Distribution of the genetic variants detected in the 21 patients with a DLCN score $>8$. CNV: copy number variations; $L D L R$ : lipoprotein receptor gene; $L I P C$ : lipase $C$ gene; CYP27A1: cytochrome P450 family 27 type A1 gene; APOB: apolipoprotein b gene; $A P O E$ : apolipoprotein $\mathrm{E}$ gene; LIPA: lipase A gene.

one of the cases with a negative genetic study and the carrier of the genetic variant in the LIPA gene were carriers of a deletion of exons 16-18 and one duplication of exons 2-8, respectively, in the LDLR gene (Table 1).

Regarding the calculation of GRS, five of the 21 patients had a higher GRS at the cutoff value of 1.96 established at the $90^{\text {th }}$ percentile, although these cases were also carriers of variants in $\operatorname{LLR}(\mathrm{n}=2)$ and cases with variants in $A P O B / A P O E, C Y P 27 A 1$ and LIPC. It should be noted that $6(28 \%)$ of the 21 patients with a DLCN score $>8$ did not show any type of genetic alteration after the extended genetic study and the detection of polygenic causes (Fig. 1).

\section{Discussion}

$\mathrm{FH}$ is a monogenic disease with high penetrance, classically associated with variants in the $L D L R, A P O B$, and PCSK9 genes ${ }^{1}$. Current wide availability of genetic studies, in part due to cost reduction, has allowed deepening the study of patients with $\mathrm{FH}$ phenotype and establishing a correlation between clinical suspicion and the results of the sequencing of genes potentially participating in cholesterol metabolism.

After FH is clinically suspected, the procedure that follows is the application of a clinical score or diagnostic criteria to establish FH clinical diagnosis. The most widely used clinical-biochemical criteria are DLCN, where, based on five items, it is concluded if the patient has a definite (> 8 points), probable (6-8), possible (3$5)$, or improbable diagnosis $(<3)^{3}$.

Genetic analysis, looking for the genetic variant, is the next step, provided there are the resources and instruments necessary to carry out the sequencing ${ }^{15}$.

Identification of the genetic variant allows to better characterize the patient; the different mutations guide about disease prognosis; and it is possible to carry out a family cascade screening and, in selected cases, support specific therapeutics ${ }^{16,17}$.

During the development of the Da Vinci Study (Estudio Argentino Prevalencia en Hipercolesterolemia Familiar), 246 patients with increased levels of cholesterol and/or LDL-C were assessed, of which $21 \mathrm{had}$ a DLCN score $>8$, i.e., a FH definite diagnosis. These patients were studied with genetic sequencing for the detection of monogenic variants, with an expanded panel of 23 genes, added to an analysis of large rearrangements; finally, a polygenic score (PGS) of 10 SNPs related to LDL-C increase was applied. Of the 21 patients, 10 had variants in $L D L R$, one in $A P O B$ together with $A P O E$, one in $L I P C$, and one in CYP27A1; they had also an elevated PGS, and two patients had one deletion and one duplication (genetic rearrangements) in $L D L R$, the latter with one variant in LIPA.

It should be noted that six of the 21 patients with a score $>8$ showed no genetic alterations. Therefore, this $28 \%$ of patients comprises the category of subjects with $\mathrm{FH}$ phenotype and negative genetic study, keeping in mind that, in the present study, the evaluated gene panel was expanded and included polygenic causes, which further adds value to the finding ${ }^{18}$.

Possible explanations for this finding would be the following: (a) existence of variations or mutations in genes not yet recognized as causative of $\mathrm{FH}$; (b) presence of mutations in regions not detected by currently available technologies, such as mutations mapped in deep intronic or promoter distal zones; (c) effects of the environment on genes (epigenetic phenomena), and (d) interactions between different genes in a single individual ${ }^{19-21}$.

On the other hand, DLCN score validation in this population for clinical diagnosis, as well as GRS, is necessary to confirm its usefulness in this setting and ensure its specificity and diagnostic sensitivity ${ }^{10,14}$.

Implementation of the expanded gene panel beyond those typically associated with FH has allowed recognizing unusual variants related to severe hypercholesterolemia ${ }^{13}$. In this study, one patient showed a variant 
in the lysosomal acid enzyme gene (LIPA), the deficiency of which has been linked to dyslipidemia and premature mortality ${ }^{22}$. This patient is a double heterozygote, since she also showed a duplication in $L D L R$; either way, the variant in LIPA is of uncertain significance. Other variants in uncommon genes that were identified in patients with a definite $\mathrm{FH}$ diagnosis were detected in the hepatic lipase gene (LIPC) and in CYP27A1 in association with cerebrotendinous xanthomatosis. However, those variants also coexisted with high GRS, which indicates polygenic causes. Therefore, the alteration mostly that causes elevated LDL-C remains to be elucidated, since polygenic causes or variants in unusual genes whose pathogenicity is still uncertain can coexist ${ }^{10}$.

Current usefulness of genetic studies for therapeutic decision-making is not established. It would be useful in cases of patients with homozygous $\mathrm{FH}$, to quantify LDL receptor residual activity, but not in most FH cases. Therefore, LDL-c level and patient overall risk should be the determining factors regarding the therapeutic behavior in patients with $\mathrm{FH}^{18.20}$.

It can be concluded that, despite an exhaustive and expanded search for genetic causes in patients with a definite $\mathrm{FH}$ clinical diagnosis, $28 \%(6 / 21)$ of patients showed no genetic alteration. Future and more complex studies, such as performing exomes to different members of a single family, perhaps will finish demonstrating and explaining the referred findings.

\section{Conclusion}

Finally, in the analyzed cohort in a specific region of the Province of Buenos Aires, $28 \%$ of patients with a $\mathrm{FH}$ clinical diagnosis (DLCN) had no genetic alterations after having carried out an extensive analysis, not only of the variants in common genes related to $\mathrm{FH}$ but also after having studied genes considered non-classical and having applied a GRS to assess the polygenic contribution of elevated LDL-C and, finally, after a bioinformatics analysis to identify large rearrangements in the structure of genes not recognized by genetic sequencing.

\section{Acknowledgments}

The authors express their gratitude to doctors Ernst Schaefer, Eliana Polisecki, Andrew Geller (Boston Heart Diagnostics, Framingham, MA, USA) and Robert Hegele (Robarts Research Institute, London, Ontario,
Canada) for the execution of the genetic study and the advice received.

\section{Funding and conflicts of interest}

This work was carried out with unrestricted subsidy from Amgen Biotechnology Company, CA, USA and subsidy granted by the University of Buenos Aires, UBACYT 20020170100259BA; Pablo Corral: Amgen Biotechnology Company and Sanofi Pharmaceutical Company; Laura Schreier: Sanofi Pharmaceutical Company.

\section{Ethical disclosure}

Protection of people and animals. The authors declare that the procedures followed were in compliance with the ethical standards of the responsible human experimentation committee and in accordance with the World Medical Association and the Declaration of Helsinki.

Confidentiality of data. The authors declare that they have followed the protocols of their work center on the publication of patient data.

Right to privacy and informed consent. The authors have obtained informed consent of the patients or subjects referred to in the article. This document is in the possession of the corresponding author.

\section{References}

1. Nordestgaard BG, Chapman MJ, Humphries SE, Ginsberg HN, Massana L, Descamps OS, et al. Familial hypercholesterolaemia is underdiagnosed and undertreated in the general population: guidance for clinicians to prevent coronary heart disease: Consensus Statement of the European Atherosclerosis Society. Eur Heart J 2013; 34:3478-3490.

2. Gidding SS, Champagne MA de Ferranti SD, Defesche J, Ito MK, Knowles JW, et al. The agenda for familial hypercholesterolemia. Circulation 2015;132:2167-2192.

3. World Health Organization. Familial hypercholesterolaemia: report of a second WHO Consultation, World Health Organization, Geneva, Switzerland,1999. WHO publication No. WHO/HGN/FH/CONS/99.2.

4. Hegele RA, Ban MR, Cao H, Mclntyre AD, Robinson JF, Wang J. Target next- generation secuencing in monogenis dyslipidemias. Curr Op Lipidol 2015:26:103-13

5. Wang J, Dron JS, Ban MR, Robinson JF, Mclntyre AD, Alazzam M, et al. Polygenic versus monogenic causes of hypercholesterolemia ascertained clinically. Arterioscler Thromb Vasc Biol 2016;36:2439-2445.

6. Sarraju A, Knowles JW. Genetic testing and risk scores: impact on familial hypercholesterolemia. Front Cardiovasc Med 2019; 29;6:5.

7. Sharifi M, Futema M, Nair D, Humphries SE. Genetic architecture of familial hypercholesterolaemia. Curr Cardiol Rep 2017;19 (5):44.

8. Lázaro P, Pérez de Isla L, Watts GF, Alonso R, Muñiz O, Fuentes F, et al. Cost-effectiveness of a cascade screening program for the early detection of familial hypercholesterolemia. J Clin Lipidol 2017;11(1):260-271.

9. Talmud PJ, Shah S, Whittall R, Futema M, Howard P, Cooper JA, et al. Use of low-density lipoprotein cholesterol gene score to distinguish patients with polygenic and monogenic familial hypercholesterolaemia: a case-control study. Lancet 2013;381:1293-1301.

10. Hooper AJ, Burnett JR, Bell DA, Watts GF. The present and the future of genetic testing in familial hypercholesterolemia: opportunities and caveats. Curr Atheroscler Rep 2018;20(6):31. 
11. Haralambos $K$, Whatley SD, Edwards R, Gingell R, Townsend D, Ashfield-Watt $P$, et al. Clinical experience of scoring criteria for familial hypercholesterolaemia $(\mathrm{FH})$ genetic testing in Wales. Atherosclerosis 2015;240:190-196.

12. Miller SA, Dykes DD, Polesky HF. A simple salting out procedure for extracting DNA from human nucleated cells. Nucleic Acids Res 1988;16 (3):1215

13. Corral P, Geller AS, Polisecki EY, López Gl, Bañares VG, Cacciagiu L, et al. Unusual genetic variants associated with hypercholesterolemia in Argentina. Atherosclerosis 2018;277:256-261.

14. lacocca MA, Hegele RA. Recent advances in genetic testing for familial hypercholesterolemia. Expert Rev Mol Diagn 2017;17 (7):641-651.

15. lacocca MA, Wang J, Dron JS, Robinson JF, Mclntyre AD, Cao H, et al. Use of next-generation sequencing to detect LDLR gene copy number variation infamilial hypercholesterolemia. J Lipid Res 2017;58(11):2202-2209

16. Berberich AJ, Hegel RA, The complex molecular genetics of familia hypercholesterolaemia. Nat Rev Cardiol 2018. https://doi.org/10.1038/ s41569-018-0052-6.

17. Sturn AC, Knowlwes JW, Gidding SS, Amad ZS, Ahmed CD, Ballantayne CM, et al. Genetic testing for familial hypercholesterolemia: JACC Scientific Expert Panel. J Am Cardiol 2018;72(6):662-680.
18. Santos RD. Phenotype vs genotipe in severe familial hypercholesterolemia: What matters for the clinician? Curr Op Lipidol 2017; 28(2):130-135.

19. Guay SP, Brisson D, Lamarche B, Gaudel D, Bouchard L. Epipolymorphisms within lipoprotein genes contribute independently to plasma lipid levels in familial hypercholesterolemia. Epigenetics 2014; 9(5):718-29.

20. Santos RD, Guidding SS, Hegele RA, Cuchel MA, Barter PJ, Watts GE, et al. Defining severe familial hypercholesterolaemia and the implications for clinical management a consensus statement from the Intenational Atherosclerosis Society Severe Familial Hypercholesterolemia Panel. Lancet Diabetes Endocrinol 2016;4(10):850-61.

21. Futema M, Plagnol V, Li K, Whittall RA, Neil HA. Whole exome sequencing of familial hypecholesterolaemia patients negative for LDLR/APOB/ PCSK9 mutations. J Med Genet 2014;51:537-544.

22. Chora JR, Alves AC, Medeiros AM, Mariano C, Loberinhas G, Guerra A, et al. Lysosomal acid deficiency: a hidden disease among cohorts of familial hypercholesterolemia? J Clin Lipidol 2017;11(2):477-484.e2. 